\title{
Coxsackie viral myocarditis
}

\author{
John B. O'Connell ${ }^{1}$ and John A. Robinson ${ }^{2}$
}

${ }^{1}$ Section of Cardiology and ${ }^{2}$ Section of Clinical Immunology, Department of Medicine, Loyola University Medical Center, Maywood, Illinois 60153, USA.

\begin{abstract}
Summary: Coxsackie viral myocarditis is a common disease, yet idiopathic dilated cardiomyopathy is a less common consequence. Insights gained from studying the Coxsackie virus B-3 murine model of myocarditis has led to the hypothesis that an acute Coxsackie viral myocarditis can result in persistent, non-viral mediated cellular responses that result in a chronic inflammatory state leading to progressive myocyte loss and ultimate development of dilated cardiomyopathy. Although the evidence linking myocarditis to dilated cardiomyopathy is circumstantial in man, the identification of defects in immunoregulation may provide the impetus to further research into the pathogenesis and ultimately the development of more rational therapies directed at modulating immune responses to alter the natural history of clinical dilated cardiomyopathy.
\end{abstract}

\section{Introduction}

Although viruses have been implicated as a common aetiology of human cardiac disease, a causative role has been difficult to prove. One-half of patients with acute myocarditis and one-third with acute pericarditis have had a concomitant Coxsackie B virus infection (Grist \& Bell, 1974). Since clinical infection with Coxsackie B virus is common and most cases of acute myocarditis are subclinical with uneventful recovery, the epidemiological significance of linking this viral infection to acute myocarditis is open to serious question.

The recent postulate that viral myocarditis may lead to chronic dilated cardiomyopathy (DC) in some individuals underscores the importance of the need for a more complete understanding of the role of initial viral infections in inciting the complex immunological responses that ultimately lead to persistent chronic myocardial inflammation and DC (Robinson \& O'Connell, 1983). Moreover, since no specific therapy for primary myocardial disease exists, a further understanding of the pathogenesis of viral-initiated myocardial perturbations may lead to the development of therapies designed to treat the cause rather than the effect (congestive heart failure) of DC.

Since the initial myocarditis may be subclinical and undetected before the onset of chronic cardiac disease, full understanding of the progressive pathogenesis of myocardial damage may be impossible in man. Insights gained from studying Coxsackie virus B-3

Correspondence: J.B. O'Connell, M.D., Section of Cardiology, Department of Medicine, Loyola University Medical Center, Maywood, Illinois 60153, USA.
(CVB-3)-induced myocardial dysfunction in animal systems may result in the development of diagnostic and therapeutic modalities that can be directly applied to humans.

\section{Murine Coxsackie B-3 myocarditis}

The murine CVB-3 myocarditis model is ideally suited for the study of the pathogenesis and modification of immune responses to prevent a chronic cardiomyopathy that may follow the initial viral myocarditis. Serial studies have documented the evolution of murine CVB-3 myocarditis from an acute viral syndrome to chronic DC, a scenario that seems to parallel the pathophysiology in human disease. When weanling mice are infected with CVB-3, an acute myocarditis results (Table I) (Woodruff, 1980). The viraemic phase is limited to 3 or 4 days and the virus is cultured from the myocardium only up to the tenth day. A generalized, nonspecific cellular response to viral

Table I Characteristics of the acute phase of murine Coxsackie B-3 myocarditis

- Myocardial viral replication for 7-9d

- Viral clearance mediated by B-lymphocytes and macrophages

- Fatal when pretreated with cyclophosphamide or corticosteroids

- Unaffected by prior bone marrow irradiation/reconstitution with thymectomy or anti-thymocyte serum 
injury has been noted in other tissues during the acute viral infection (Burch \& Harb, 1981). The myocardial necrosis that occurs early is patchy, affecting only isolated myofibres and leaving adjacent myofibres intact. Neutralizing virus-specific antibodies are detected in the serum on the seventh day and remain elevated for several months (Kitaura, 1981b). Despite the-absence of cultural virus, a lymphomononuclear inflammatory infiltrate is present in the hearts of Swiss ICR mice at 6 months after the initial infection (Table II). Histopathology in these animals with persistent inflammation includes fibrosis, dystrophic mineralization, and myocardial hypertrophy (Wilson et al., 1969). By 15 months, there is hypertrophy, mural thrombi, myocardial disintegration, and fibrous scarring Reyes et al., 1981. These findings are exacerbated if the mice are subjected to daily periods of strenuous exercise (swimming) during the acute phase. At 15 months, the lymphomononuclear infiltration is no longer present. The pathology in Swiss ICR mice is identical to that described at autopsy in patients with idiopathic DC. Even the electrocardiographic abnormalities, which include AV block, ventricular and atrial premature contractions, and left bundle branch block are similar to electrocardiographic changes in human dilated cardiomyopathy (Kawai et al., 1982). Identification of the biphasic (acute-viral and chronicnonviral mediated) nature of murine myocarditis has led to conjecture about the pathogenesis of immunemediated potential of myocardial damage. When weanling and adult mice are infected with CVB-3, the virus is no longer detectable in the myocardium after the eighth day (Woodruff \& Woodruff, 1974). When mice are pretreated with anti-thymocyte serum or given sublethal bone marrow irradiation and thymectomy, thus diminishing cell-mediated immune responses, the acute viral-mediated phase of the illness remains unchanged. The virus is cleared normally and viral antibody titres are normal. Survival is dramatically improved and inflammation is markedly attenuated

Table II Characteristics of the chronic phase of murine Coxsackie B-3 myocarditis

- Absence of culturable virus

- Mediated by T-lymphocytes (and/or NK cells)

- Attenuated by bone marrow irradiation/ reconstitution and thymectomy

- Pathology

6 months

- hypertrophy, fibrosis, and inflammation

1 year

- hypertrophy, fibrosis, and mural thrombi without inflammation during the chronic phase. These studies imply that $\mathrm{T}$ lymphocytes (T-Ly), the primary effectors of cellmediated cytotoxic responses, do not participate in the acute phase and are not responsible for viral clearance, yet play a major role in the chronic phase. This biphasic nature of immunological responses allows a treatment 'window' to be established.

Immunosuppressive agents that affect cell-mediated immune responses selectively when given after viral replication may successfully attenuate the chronic inflammatory response. Although T-Ly play little role in the acute phase, the actual effects on viral clearance are as yet undefined (Rager-Zisman \& Allison, 1973a,b; Chaturvedi et al., 1978; Woodruff \& Woodruff, 1971; Woodruff, 1979). Viral clearance may actually result from the complex interaction of interferon, humoral antibodies, B-lymphocytes, and macrophages (Norris \& Loh, 1973). Attenuation at any of these levels of host immune response during the early phase may result in overwhelming viral dissemination. The study of viral clearance in the murine CVB-3 model may not, however, be relevant to studies that assess treatment in human disease. Several factors, including the delay in seeking medical attention and the subclinical nature of human viral myocarditis, may make identification of the illness during the phase of acute viral replication an unusual occurrence.

The immunopathogenesis of the chronic non-infec tious phase is theoretically vulnerable to specific modulation of immune responses which could inhibit or reverse a similar inflammatory reaction in man. The role of T-Ly in the chronic phase was implicated when splenic lymphocytes were harvested from previously infected mice (Wong et al., 1977). These lymphocytes were specifically toxic to target cells previously infected with CVB-3, but did not lyse uninfected myocardium, liver, or kidney; this implies that T-Ly may be responsible for the myocardial necrosis seen in chronic myocarditis. Myocardial necrosis without a lymphomononuclear infiltrate was not prominent in the hearts of athymic nude mice (absent T-Ly) infected with CVB-3 in a previously published study (Hashimoto \& Komatsu, 1978). However, we have documented the development of the chronic inflammatory reaction in athymic nude mice (Robinson et $a l .$, 1981). When CVB-3 myocarditis was induced in athymic mice (nu/nu on a BALB/c background), viral clearance was similar to BALB/c controls. Both developed inflammatory infiltrates during the chronic phase. The infiltrates in the athymic nudes consisted of lymphomononuclear cells, which were alpha-naphthyl acetate esterase positive implying a T-cell lineage. These cells histologically resemble natural killer (NK) cells. Athymic nude mice have no T-Ly, but have increased numbers of NK cells, and in some circumstances, NK cells are known to be the effectors of chronic cell-mediated immune responses in these 
animals. The role of NK cells and T-Ly cells in the chronic phase needs further clarification. Therapies designed may ultimately require efficacy in suppressing both NK and T-Ly responses.

The antigen responsible for stimulating cellmediated immune responses during the chronic phase in murine myocarditis is unknown. Serial studies in murine CVB-3 infection demonstrate rapid disappearance of viral antigens during the acute phase (Feinstone et al., 1973; Roesing et al., 1979). T-Ly from previously infected CVB-3 mice do not lyse uninfected myofibres, implying that viral antigens do not cross-react with myocardial antigens (Huber et al., 1980). Antigens extracted with hypertonic salt (KC1) extracts from the hearts of CVB- 3 infected mice are not neutralized by viral antibodies, yet are capable of inhibiting cell migration of specifically immune peritoneal exudate cells obtained from previously immunized mice (Paque et al., 1978). These results indicate that a novel antigen developed from myocardial tissue as a result of CVB-3 infection, and may serve as the stimulus to further cell-mediated immune reaction. An identical antigen has been detected in baboon hearts following CVB-3 infection (Paque et al., 1981). When virus-specific cytotoxic lymphocytes and autoreactive cytotoxic lymphocytes (a population which preferentially absorb to and lyse uninfected myocytes) are transferred to T-Ly deficient mice, myocarditis could be induced by both cell populations, although the lesions caused by the autoreactive cytotoxic lymphocytes were more necrotizing than those from virus-specific cells (Huber \& Lodge, 1984). In this system, it appears that CVB-3-induced myocarditis may also result from autoimmunity to myocyte antigens.

In summary, the acute phase of murine CVB-3 myocarditis is characterized by active viral replication and humoral and monocytic immune responses directed to viral clearance. During this phase, cytotoxic TLy and possibly NK cells directed toward a neoantigen or possibly pre-existent myocyte antigens act as the effectors of the chronic myocardial damage. The chronic inflammatory response ultimately leads to a clinical and pathological picture reminiscent of human dilated cardiomyopathy.

\section{Human Coxsackie myocarditis}

Evidence that Coxsackie virus causes human myocarditis is limited to isolation of the virus from myocardium as reported in only two patients (Sutton et al., 1967; Longson et al., 1969). A 'moderate order association' (Lerner et al., 1975) of Coxsackie virus B with myocarditis has been made by the correlation of neutralizing antibody titres or isolation of the virus from rectal or nasopharyngeal swabs with acute myocarditis (Bell \& Grist, 1968; Freij et al., 1970; Smith, 1970; Koontz \& Ray, 1971; Schmidt et al., 1973; Toshima et al., 1979). The incidence of elevated titres to enteroviruses is greater in patients with chronic congestive heart failure due to primary myocardial disease than in the general population of patients with heart disease of other aetiology (Table III) (Cambridge et al., 1979; Falase et al., 1979; Kitaura, 1981a; Lau, 1982), and the progression from acute CVB myocarditis to a chronic dilated cardiomyopathy has only been described in isolated patients (Burch \& Colcolough, 1969; Frenkel, 1972; Rose, 1973; Barson et al., 1981; Morita et al., 1983). Also, in patients without clinical myocarditis, from whom Coxsackie B virus was isolated in the nasopharynx, a high incidence of subsequent chronic congestive heart failure has been documented (Orinius, 1968). Lastly, $25 \%$ of patients with serological evidence of Coxsackie viral infection during acute myocarditis develop dilated cardiomyopathy (Sainani et al., 1968).

Table III Evidence linking acute viral myocarditis to dilated cardiomyopathy in man

1. Elevated enteroviral antibody titres in dilated cardiomyopathy.

2. Progressive clinical syndrome initiated with viral myocarditis culminating in dilated cardiomyopathy.

3. High incidence of heart failure on follow-up of patients with nasopharyngeal isolation of Coxsackie $B$ virus in the absence of clinical acute myocarditis.

4. High incidence of dilated cardiomyopathy on long term follow-up of patients who recovered from acute viral myocarditis.

Since the incidence of myocarditis during Coxsackie B infection is high, and DC low, inferences from the animal model suggest that identification of patients likely to develop a chronic cardiomyopathy lies in the understanding of the regulation of cytotoxic responses. Cell-mediated immune responses in patients with predominantly Coxsackie B myocarditis are augmented (Hori et al., 1982; Maisch et al., 1982). Lymphocytic cytotoxicity against myocardial cells in vitro can be detected in $30 \%$ of patients with DC (Jacobs $e t$ al., 1979). Subtle defects in immunoregulation may identify that subset of patients likely to develop chronic cytotoxic responses following the initial viral infection. In this regard, a defect in suppressor lymphocyte function has been identified in a subset of patients with dilated cardiomyopathy and myocarditis (Eckstein et al., 1982; Fowles et al., 1979). Furthermore, deficient natural killer cell activity has been shown in a similar population (Anderson et al., 
1982). Although HLA haplotypes have been associated with idiopathic dilated cardiomyopathy (Anderson et al., 1984), these studies need verification before firm conclusions can be drawn.

\section{References}

ANDERSON, J., CARLQUIST, J. \& HAMMOND, E. (1982). Deficient natural killer cell activity in patients with idiopathic dilated cardiomyopathy. Lancet, ii, 1124.

ANDERSON, J., CARLQUIST, J., LUTZ, J., DEWITT, C. \& HAMMOND, E. (1984). HLA A, B and DR typing in idiopathic dilated cardiomyopathy: a search for immune response factors. American Journal of Cardiology, 53, 1326.

BARSON, W., CRAENEN, J., HOSIER, D., BRAWLEY, R. \& HILTY, M. (1981). Survival following myocarditis and myocardial calcification following infection by Coxsackie virus $\mathrm{B}_{4}$. Pediatrics, 68, 79.

BELL, E. \& GRIST, N. (1968). Coxsackie virus infections in patients with acute cardiac disease and chest pain. Scottish Medical Journal, 13, 47.

BURCH, G. \& COLCOlough, H. (1969). Progressive Coxsackie viral pancarditis and nephritis. Annals of Internal Medicine, 71, 963.

BURCH, G. \& HARB, J. (1981). Lesions induced by encephalomyocarditis virus and Coxsackie virus B myocarditis in newborn mice. Archives of Pathology and Laboratory Medicine, 103, 348.

CAMBRIDGE, G., MACARTHUR, C.G.C., WATERSON, A.P., GOODWIN, J.F. \& OAKLEY, C.M. (1979). Antibodies to Coxsackie B viruses in congestive cardiomyopathy. British Heart Journal, 41, 692.

CHATURVEDI, U., TANDON, H. \& MATHUK, A. (1978). Control of in vitro and in vivo spread of Coxsackie virus $\mathrm{B}_{4}$ infection by sensitized spleen cells and antibody. Journal of Infectious Diseases, 138, 181.

DEGUCHI, H. (1981). Ultrastructural alterations of the myocardium in Coxsackie $\mathbf{B}_{3}$ virus myocarditis in mice. Japanese Circulation Journal, 45, 694.

ECKSTEIN, R., MEMPEL, W. \& BOLTE, H.D. (1982). Reduced suppressor cell activity in congestive cardiomyopathy and myocarditis. Circulation, 65, 1224.

FALASE, A., FABIYI, A. \& ODEGBO-OLUKOYA, O. (1979). Coxsackie B viruses and heart muscle disease in Nigerian adults. Tropical and Geographical Medicine, 31, 237.

FEINSTONE, S., HENSLEY, G. \& RYTEL, M. (1973). Post Coxsackie virus $\mathrm{B}_{3}$ myocardiopathy in mice. Proceedings of the Society for Experimental Biology and Medicine, 144, 345.

FOWLES, R.E., BIEBER, C.P. \& STINSON, E.B. (1979). Defective in vivo suppressor cell function in idiopathic cardiomyopathy. Circulation, 59, 483.

FREIJ, L., NORRBY, R. \& OLSSON, B. (1970). A small outbreak of Coxsackie $B_{5}$ infection with two cases of cardiac involvement and orchitis followed by testicular atrophy. Acta Medica Scandinavica, 187, 177.

FRENKEL, H. (1972). Cardiomyopathy due to Coxsackie B. Journal of the Iowa Medical Society, 62, 527.

GRIST, N. \& BELL, E. (1974). A six year study of Coxsackie virus B infections in heart disease. Journal of Hygiene, 73, 165.

\section{Acknowledgements}

This study was supported in part by the Earl M. Bane Charitable Trust.

HASHIMOTO, I. \& KOMATSU, T. (1978). Myocardial changes after infection with Coxsackie virus $\mathrm{B}_{3}$ in nude mice. British Journal of Experimental Pathology, 59, 13.

HORI, H., MATOBA, T., SHINGU, M. \& TOSHIMA, H. (1982). The role of cell mediated immunity in Coxsackie B viral myocarditis. Japanese Circulation Journal, 45, 1409.

HUBER, S., JOB, L. \& WOODRUFF, J. (1980). Lysis of infected myofibers in Coxsackie virus $\mathrm{B}_{3}$ immune lymphocytes. American Journal of Pathology, 98, 581.

HUBER, S. \& LODGE, P. (1984). Coxsackie virus $B_{3}$ myocarditis in BALB/c mice. Evidence for autoimmunity to myocyte antigens. American Journal of Pathology, 116, 21.

JACOBS, B., MATSUDA, Y., DEODHAR, S. \& SHIREY, E. (1979). Cell-mediated cytotoxicity to cardiac cells of lymphocytes from patients with primary myocardial disease. American Journal of Clinical Patholology, 72, 1.

KAWAI, C., KISHIMOTO, C., HOSHIMO, T., MATSUMORI, A. \& IMAI, J. (1982). Electrocardiographic findings in experimental myocarditis. Japanese Circulation Journal, 46, 310.

KITAURA, Y. (1981a). Virological study of idiopathic cardiomyopathy. Serological study of virus antibodies and immunofluorescent study of myocardial biopsies. Japanese Circulation Journal, , 45, 279.

KITAURA, Y. (1981b). Experimental Coxsackie B virus myocarditis in mice. Japanese Circulation Journal, 45, 757.

KOONTZ, C. \& RAY, C. (1971). The role of Coxsackie group B virus infections in sporadic myopericarditis. American Heart Journal, 82, 750 .

LAU, R. (1982). Coxsackie B virus infection in acute myocardial infarction and adult heart disease. Medical Journal of Australia, 2, 520.

LERNER, A., WILSON, F. \& REYES, M. (1975). Enteroviruses and the heart (with special emphasis on the probable role of Coxsackie viruses, group B, types 1-5). II. Observations in humans. Modern Concepts in Cardiovascular Disease, 44 (3), 11.

LONGSON, M., COLE, F. \& CAVIES, D. (1969). Isolation of a Coxsackie virus group B, type 5 , from the heart of a fatal case of myocarditis in an adult. Journal of Clinical Pathology, 22, 654.

MAISCH, B., TROSTEL-SOEDER, R., STECHEMESSER, E., BERG, P.A. \& KOCHSIEK, K. (1982). Diagnostic relevance of humoral and cell-mediated immune reactions in patients with acute viral myocarditis. Clinical Experimental Immunology, 48, 533.

MORITA, H., KITAURA, Y., DEGUCHI, H., KOTAKA, M., NAKAYAMA, Y., SUWA, M., KINO, M., HIROTA, Y. \& KAWAMURA, K. (1983). Coxsackie $B_{5}$ myopericarditis in a young adult. Clinical course and endomyocardial biopsy findings. Japanese Circulation Journal, 47, 1077.

NORRIS, D. \& LOH, P. (1973). Coxsackie virus myocarditis: prophylaxis and therapy with an interferon stimulator. Proceedings of the Society for Experimental Biology and Medicine, 143, 133. 
ORINIUS, E. (1968). The late prognosis after Coxsackie B infection. Acta Medica Scandinavica, 183, 235.

PAQUE, R., GAUNTT, C., NEALON, T. \& TROUSDALE, M. (1978). Assessment of cell-mediated hypersensitivity against Coxsackie virus B3 induced myocarditis utilizing hypertonic salt extracts of cardiac tissue. Journal of Immunology, 120, 1672.

PAQUE, R., GAUNTT, C. \& NEALON, T. (1981). Assessment of cell mediated immunity against Coxsackie viral $B_{3}$ induced myocarditis in a primate model. Infectious Immunology, 31, 470.

RAGER-ZISMAN, B. \& ALLISON, A. (1973a). The role of antibody and host cells in the resistance of mice against infection by Coxsackie $B_{3}$ virus. Journal of General Virology, 19, 329.

RAGER-ZISMAN, B. \& ALLISON, A. (1973b). Effects of immunosuppression on Coxsackie $B_{3}$ virus infection in mice, and passive protection by circulating antibody. Journal of General Virology, 19, 339.

REYES, M., KHANG-LOON, H., SMITH, F. \& LERNER, A. (1981). A mouse model of dilated type cardiomyopathy due to Coxsackie virus $\mathbf{B}_{3}$. Journal of Infectious Diseases, 144, 232.

ROBINSON, J., O'CONNELL, R., ROEGES, L., MAJOR, E. \& GUNNAR, R. (1981). Coxsackie B3 myocarditis in athymic mice. Proceedings of the Society for Experimental Biology and Medicine, 166, 80.

ROBINSON, J. \& O'CONNELL, J. (eds). (1983). In Myocarditis: Precursor of Cardiomyopathy, p. 158. D.C. Heath \& Co: Lexington, Ma.

ROESING, T., LANDAU, B. \& CROWELL, R. (1979). Limited persistence of viral antigen in Coxsackie virus $B_{3}$ induced heart disease in mice. Proceedings of the Society for Experimental Biology and Medicine, 160, 382.

ROSE, H. (1973). Recurrent illness following acute Coxsackie $\mathrm{B}_{4}$ myocarditis. American Journal of Medicine, 54, 544.

SAINANI, G., KROMPOTIC, E. \& SLODKI, S. (1968). Adult heart disease due to the Coxsackie virus B infection. Medicine, 47, 133.
SCHMIDT, N., MAGOFFIN, R. \& LENNETTE, E. (1973). Association of group B Coxsackie viruses with cases of pericarditis, myocarditis, or pleurodynia by demonstration of immunoglobulin $\mathrm{M}$ antibody. Infection and Immunity, 8, 341.

SMITH, W. (1970). Coxsackie B myopericarditis in adults. American Heart Journal, 80, 34.

SUTTON, G., HARDING, H., TREHART, R. \& CLARK, H. (1967). Coxsackie $B_{4}$ myocarditis in an adult: successful isolation of virus for ventricular myocardium. Aerospace Medicine, 38, 66.

TOSHIMA, H., OHKITA, Y. \& SINGU, M. (1979). Clinical features of acute Coxsackie B viral myocarditis. Japanese Circulation Journal, 43, 441.

WILSON, F., MIRANDA, Q., CHASON, J. \& LERNER, A. (1969). Residual pathologic changes following murine Coxsackie A and B myocarditis. American Journal of Pathology, 55, 253.

WONG, C., WOODRUFF, J. \& WOODRUFF, J. (1977). Generation of cytotoxic $T$ lymphocytes during Coxsackie virus $B_{3}$ infection. II. Characterization of effector cells and demonstration of cytotoxicity against viral infected myofibers. Journal of Immunology, 118, 1165.

WOODRUFF, J. \& WOODRUFF, J. (1971). Modification of severe Coxsackie virus $B_{3}$ infection in marasmic mice by transfer of immune lymphoid cells. Proceedings of the National Academy of Science, 58, 2109.

WOODRUFF, J. \& WOODRUFF, J. (1974). Involvement of Tlymphocytes in the pathogenesis of Coxsackie virus $B_{3}$ heart disease. Journal of Immunology, 113, 1726.

WOODRUFF, J. (1979). Lack of correlation between neuralizing antibody production and suppression of Coxsackie virus $\mathbf{B}_{3}$ replication in target organs: evidence of involvement of mononuclear inflammatory cells in host defence. Journal of Immunology, 123, 31.

WOODRUFF, J. (1980). Viral myocarditis - a review. American Journal of Pathology, 101, 427. 